\title{
New Orthodox Immigration in Finland
}

\author{
TUOMAS MARTIKAINEN, Ph.D., Researcher \\ Department of Comparative Religion, Åbo Akademi University, \\ Turku, Finland
}

\begin{abstract}
The Finnish Orthodox Church is the second largest religious organization in Finland with ca. 57,000 members. During the last 15 years its membership has grown 7\% because of international migration. The migrants are mainly from the former Soviet Union (e.g. Estonia, Russia and Ukraine), but there are also small groups from, e.g., Greece, Ethiopia and Romania. The article is a case study of the immigrant activities in two Orthodox parishes that are located in Helsinki and Turku. Issues such as organizational support, religious education and transnational connections are presented. Based on contemporary research on religion and immigration, the article aims to highlight the specific role of language in immigrant organizations, and it argues that more attention should be given to it as a specific factor.
\end{abstract}

Keywords: Religion, international migration, immigration, structural adaptation, globalization, Orthodox Christianity, language

\section{Introduction}

International migration is a major agent of contemporary local religious change (Baumann 2000; Hinnels 1997; Warner 1998). A number of social scientists have raised the immigrants' local experiences and lives to a central position in order to further our understanding of the general globalization process (for instance, Ebaugh and Chafetz 2002). Within the broader discussion I am positioning myself among those who seek the answers in local transformations, hybrid forms and in the ongoing debates of what is suitable action in a particular context (Hannerz 1996; Held et al. 1999, 3-10). In the following, reference will be made to the continuing importance of the local context in our attempt to understand major cultural and religious changes in the globalizing world. Many of the changes are happening at the grassroots level, in the individual lives of immigrants as well as in local religious organizations. These again are subject to national and transnational structures that condition local transformations. It is the increasingly globalized world that makes the study of locality and local processes topical but also complex (Eade 1997; Robertson 1995). What exactly are local processes and when does the inquiry turn towards larger arenas? 
Orthodox Christianity is one of those religious traditions that has become a religion of diaspora. The collapse of the Soviet Union and the Eastern bloc opened doors for large scale emigration at the turn of the 1990s, but even before that post-war migration, for instance, from Greece and the Middle East had led to the establishment of diaspora communities in Europe, North America and Australia. In Finland, Orthodox Christianity is both a traditional minority as well as a new immigrant church. Due to historical reasons, it has a strong legal position almost equivalent to that of the majority's Evangelical Lutheran Church despite a membership of only one percent of the total population. In this respect, new immigrants are in a different position to those migrants that need to establish new organizations. This article will also discuss to what extent this special feature of Orthodox Christianity has affected the localization process of the new immigrants. In this setting, we may presume that the study of the particular histories of immigrants with Orthodox background can reveal new aspects of local change that we might not find in some other contexts. As we shall see, the questions are often global, but the answers are almost always local.

This article focuses on the collective efforts of immigrants with Orthodox background to pursue their religious lives in Finland. First, the article presents briefly Orthodox immigration and its history in Finland, including some remarks on existing scholarship. After that I shall clarify the theoretical framework in which the analysis takes place. The empirical part of the study is an analysis of immigrants' activities in two Orthodox parishes in the cities of Helsinki and Turku. The article attempts to provide a picture of the immigrant Orthodox activity in Finland, and it also views the developments from the perspective of globalizing local societies, where local parishes function as key places for immigrants' integration into Finnish society. A major argument proposed by this article is that the role of ethnicity is often overestimated in studies on immigrant religions, and that language as a specific factor should be given more attention.

\section{Previous research}

A number of researchers have been investigating the history of the Orthodox Church in Finland, but not much interest has been targeted at recent immigrants. An underlying current in the research has been the church's close relationship with Finnish society and an emphasis on the idea that Orthodoxy has functioned as a cultural bridge between the Russian and Finnish spheres of influence. It is safe to claim that there exists a nationalistic bias in many studies of the Orthodox Church in Finland. This is somewhat unfortunate for the contemporary effort, as questions of cultural change are not well dealt with in the literature. Existing research, nevertheless, has its merits, as the general history is fairly well documented and especially Finnish-Russian relations have been of great interest. The following and a few other contributions form the main corpus of Orthodoxy in Finland on which the current text is based. 
Ortodoksinen kirkko Suomessa ("The Orthodox Church in Finland"; Ambrosius and Haapio 1982) is a general presentation of the Orthodox Church in Finland, including many articles on different aspects of church history and ritual life. Orthodoxy in Finland: Past and Present (Purmonen 1984) is a small, English-language book presenting much of the same information in abbreviated form. Ortodoksisuutta eilen ja tänään (“Orthodoxy Yesterday and Today”; Piiroinen 2002) is a historical study of the Orthodox Parish of Helsinki, which also takes contemporary multiculturalism as one of its main areas of interest. In addition, Petri Raivo's doctoral dissertation Maiseman kulttuurinen transformaatio ("Transformation of Religious Landscapes"; 1996) and Mitro Repo’s article Ortodoksinen Suomi (“The Orthodox Finland”; 1999) both add new aspects to our understanding of the history of cultural diversity in the Finnish Orthodox Church. Furthermore, Hannu Kilpeläinen's doctoral dissertation Valamo - karjalaisten luostari? ("Valamo - the Karelian Monastery?"; 2000) on the Valamo/Valaam monastery provides excellent data on the societal climate of post-independence Finland. The same issue is set in a broader context in Teuvo Laitila's and Jyrki Loima's (2004) study Nationalism and Orthodoxy. Natalia Baschmakoff's and Marja Leinonen's (2001) study of Russian life in Finland provides an insider view of the Orthodox emigrant community from independence until World War II.

\section{A brief history}

When Christianity was established in Northern Europe, Finland was one of the last places where the borderline between Catholicism and Orthodoxy was drawn. Most of what is today considered 'Finland' became an outpost of the Roman Church', but the easternmost parts of its territory became Russian Orthodox. The border was, for a long time, also that of Sweden and Russia and it was contested through history until Russia invaded Finland in 1808-1809. During the Russian era (1809-1917), the Russian Orthodox Church was also established as a Russian-language migrant church in several urban centres, including the former capital, Turku, and the new national centre, Helsinki. Turku and Helsinki were at that time and still are among the main immigrant centres of the country. This was in strong contrast to the East Finnish parishes that were mostly Finnish speaking and rural (Purmonen 1984). There were also mainly Russian language parishes, especially in the southern parts of Karelia. From the viewpoint of this article, the Orthodox Church is presented both as an 'indigenous' as well as an 'immigrant' religion in Finland. This dual history is typical for many religious traditions that are located at cultural, religious and ethnic boundaries.

\footnotetext{
${ }^{1}$ Roman Catholicism was the main religion in Finland until the 1520s. Then the Swedish state, and Finland as part of it, departed from the tradition and took the Lutheran path as part of the Reformation in Northern Europe.
} 
Finland gained its independence in 1917 and the Orthodox Diocese of Finland separated from the Russian Church in 1918 and formed the autonomous Finnish Orthodox Church under the guidance of the Ecumenical Patriarchate of Constantinople (officially in 1923). The Orthodox Church had received a special status as a 'national church' similar to that of the Lutheran Church, which gave it a strong legally supported position (Laitila and Loima 2004, 159-161). The Russian Orthodox were by far the largest immigrant group in the new republic. In the 1920s circa 8,000 Russian-speaking Orthodox were left in the young republic ${ }^{2}$ (Murtorinne 1995, 221). Due to internal struggles in the Finnish Orthodox Church, a minority of the Russian-speakers (ca. 1500-2000) left the church and founded two new parishes in Helsinki and Viipuri. The parishes joined the Russian Church again in $1945^{3}$ (Heino 1997, 68; Nevalainen 1999, 173-178). Most of the urban Orthodox parishes remained to some extent Russian-speaking until the Karelian resettlement after the Second World War, which eventually led to the dominance of the Finnish language in all Orthodox parishes and other institutions in the country (Heino 1997, 67-68; Repo 1999). The post-Second World War era was a major transition period for the Orthodox Church, as it lost most of its property and the majority of its members were resettled around the country. Karelia, the traditional heartland of Finnish Orthodoxy, was no longer part of the Finnish nation-state. The ethnic nature of some Orthodox parishes eventually became contested, mainly through increasing Finnish language presence, but the conflicts were mostly resolved peacefully. However, questions of religious authority and practice remained topical in the church for many decades (Kilpeläinen 2000; Loima 2004, 151-194).

Other early immigrant religions in Finland included Catholic Christianity, Judaism and Tatar Islam, most of which originated in imperial Russia ${ }^{4}$. All of these groups also organized their activity during the Russian period, but officially only after independence, with the exception of the Orthodox Church, which had special statutes regarding its activity even before. For the rest, however, it was the Religious Liberty Act of 1922 that would set the official guidelines for organization. During the post-World War II period, the immigrant religious communities had found their place in Finnish society and could not be distinguished from the rest of it. Some tensions still existed as, for example, the Orthodox Church still had the reputation of ryssän kirkko ("The Russian

\footnotetext{
${ }^{2}$ It is very difficult to estimate the exact number of people of Russian origin in Finland in the post-independence time, because the numbers changed significantly from time to time due to temporary visitors, refugees, etc. (Baschmakoff and Leinonen 2001, 20-69).

${ }^{3}$ At first the new parishes joined the Russian Church as members of its West European diocese. Later they were also under the jurisdiction of Constantinople for several years (1931-1945).

${ }^{4}$ Not all members of the mentioned religious minorities originated in Russia, even though many of them did. For instance, many of the early Catholics were of South European origin. However, it was because of the politics of the multi-ethnic and multi-religious Russian Empire that these traditions were allowed to establish their religious activity on Finnish territory.
} 
Church”, pejorative) (Repo 1999, 296). The parishes and other institutions related to them had become ethnic havens, where the members could practise their religion, language and culture. None of the communities mentioned played a major role in public, but had rather chosen a quiet life on the margins of society, even though the members themselves were upwardly mobile on the social ladder. Only much later, in the mid 1970s, did the Orthodox religion become something of a fashion in the wake of a growing public interest in expressive religiosity and religious aesthetics ${ }^{5}$. If the Russian period, at least in some cities like Turku, Helsinki and Viipuri, could at times be described as multicultural, the post-independence period until the 1960s could not. It was a time of ethnic enclaves.

The Finnish Orthodox Church has always been a minority church in Finland. In 2002, its members constituted 1.1\% $(56,689)$ of the total population (see Appendix). Especially since the early 1990s, immigration from Orthodox countries has increased and today recent immigrants form ca. $7 \%$ of the church's members. The new members are mostly people from the former Soviet Union and its successive states, including Belarus, Estonia, Russia and Ukraine. Furthermore, smaller groups of people have arrived from other countries, such as Bulgaria, Ethiopia, Greece, Romania and the former Yugoslavia. About two-thirds of the new immigrants are Russian-speaking. Many of the new immigrants have joined the Finnish Orthodox Church, but a growing number of activities are taking place beside that. The Russian Church has supported the foundation of several new communities in the country and there is evidence that even some further Orthodox churches have established some activity (Nikita 2003). However, the developments are, so far, poorly documented. According to a recent survey conducted among Russian immigrants, circa one third of them state that they consider the Orthodox faith to be of importance for their lives in Finland (Pohjanpää, Paananen and Nieminen 2003, 59-60).

\section{International migration in post-war Europe}

Migration across cultural and state borders as well as through other obstacles has been typical for human beings since ancient times. The global spread of the human race is just one illustration of this characteristic. In a European perspective, since colonial times, it has been Europeans themselves that have left the continent and only during the postWorld War II times has the continent itself become a destination for immigration on a larger scale. Beside this, increasing movement between European countries has taken

\footnotetext{
${ }^{5}$ According to Teuvo Laitila (personal communication), factors contributing to the growing popular recognition of the Orthodox faith in Finland were the works of Tito Colliander, icon painting workshops and the rebuilt New Valamo monastery in Heinävesi. The contemporary New Valamo is one of the main religious tourist sites in the country and it functions as a window to Orthodox religion for many Lutherans as well. On the growing importance of expressive religiosity in Finland, see Ketola 2003.
} 
place. However, the experiences of particular local societies, regions and countries are remarkably different. These differences in migration history are, nevertheless, highly central for the ways in which immigration is experienced in particular places ${ }^{6}$.

The European post-war immigration patterns can be briefly summarized as forming two phases. The first phase began in the immediate post-war period and grew from the need of labor in some growing European economies, such as Britain, France, Germany and Sweden. These countries recruited large amounts of labor from abroad. The people came from less developed European countries (e.g., Finland, Greece, Italy and Spain), former colonies (e.g., Algeria, Indonesia and Pakistan) and other non-European societies (e.g., Turkey). The migrants were mostly young men. The states in question assumed that the migrants would later return to their countries of origin. The phase came to its end in the aftermath of the oil crises in the 1970s. During this period most European countries had only limited first-hand experience of immigrant populations (Forsander 2002, 16-17). Among the migrants were many Orthodox Christians.

The second phase started in the 1980s and has continued until today. The immigrants were increasingly refugees and asylum seekers, but also family members of the migrants of the previous phase. Migration between European societies has also continued, not least because of the expansion of the European Union and the collapse of the Eastern bloc, which has furthered the emigration of Orthodox Christians. Now the immigrant receiving societies realized that the migrants were not temporary visitors, but they were there to stay. Political programs were introduced in order to aid the integration of these people into their new home countries. This had also become necessary, because among the immigrants were now many more who had not entered the country for labor purposes, including refugees, spouses and children. During this period, those European societies that were not immigrant receiving countries in the first period also began experiencing increasing immigration. This has been the case for instance in Finland and Italy (Forsander 2002, 16-17).

Whereas migration is an age-old phenomenon, it has been argued that there are some novel features of contemporary international migrations. Stephen Castles and Mark Miller (2003) describe the current era as ‘the Age of Migration’ and identify five general, novel tendencies. First, the globalization of migration refers to the fact that migratory movements affect more countries than earlier and that the diversity of the migrants'

\footnotetext{
${ }^{6}$ For instance, Finland has only become a country of net immigration since the 1980s, whereas it was a country of net emigration from the 1950s until the 1970s. The experience is dramatically different from neighboring Sweden, which has had a significant immigrant population since the 1960s, including many Finns. Moreover, contemporary immigration is mostly an urban phenomenon, so that most places in the countryside do not have experiences of increased immigration (Pohjanpää, Paananen and Nieminen 2003).
} 
areas of origin is increasing. Second, the acceleration of migration means that there has been quantitative growth of migration in all major regions. Third, the differentiation of migration is that in most places there are people who have migrated for different reasons, e.g. refugees and labor migrants. Fourth, the feminization of migration implies that more women than earlier migrate. Fifth, the growing politicization of migration refers to the fact that issues related to immigration are becoming increasingly present on the political agendas of different societies. All these five tendencies can be found in European countries, including Finland (Pohjanpää, Paananen and Nieminen 2003).

Many researchers argue that there are even further specific characteristics of contemporary international migrations. Key words in these studies include globalization, transnationalism and diaspora. Peggy Levitt (2001) discusses the matter at some length in her study, The Transnational Villagers, and identifies important differences between new and old migrations. First, new communication and transportation technologies permit easier and more intimate connections between the country of origin and the new place of settlement, which heightens the immediacy and frequency contact. The spread of global media is a part of this. Second, there is more tolerance of cultural and ethnic pluralism, which enhances the migrants' possibilities for sustaining homeland connections and for continuing with traditional practices in the new context. The contemporary, official immigration policies in many countries are mostly based on multiculturalism that explicitly encourages keeping one's religious, cultural and ethnic traditions, confirming Levitt's observation. Even internationally, assimilative policies are considered with some suspicion.

Based on Castles and Miller (2003) and Levitt (2001), it can be argued that the contemporary migrant populations are more diverse than earlier and they have more resources at their hands to sustain this diversity in the new local context. Furthermore, the new local context in which the immigrants live reaches far beyond the local society, even to different countries and continents. Even though this transnationalism is not completely new, it is, however, more extensive, accessible and affordable due to technological innovations, such as air travel, satellite television, telephone and the Internet. Following Roland Robertson (1995), it can be argued that immigrants create global or transnational spaces in their new local environments that can be described as glocal. This conceptualization implies that traditional divisions between local, regional, national and international lives are blurred and a new broader reality beyond the nation-state is formed. This is the social space in which contemporary immigrant religions function and it leads us to ask what is the role of the local context in the increasingly globalized world. 


\section{Immigrant religions and resettlement}

Immigrants' lives in a new society and religion have often been closely connected. Sometimes the migrants affect firmly rooted local religious structures and sometimes their influence is merely of marginal importance. The importance of migrants' religious activity is best seen in a larger cultural context, where religion has been one of the main ways of supporting the migrants' identity, ethnicity and culture. Also, migrant communities often keep their religious traditions long after other indicators of their cultural tradition have sunk into oblivion. Obviously, the opposite has also sometimes happened, so that migrants have given up their traditions and religions (Gustafsson 1997, 96; Hamberg 1999). There nevertheless exists much evidence to indicate that religion, even in the contemporary world, is one of the last features of one's identity to be abandoned (Baumann 2002; Ebaugh and Chafetz 2000, 401-402). The many 'ethnic versions' of Catholicism in the United States, Judaism around the world and the various Muslim, Hindu and Buddhist communities in today's Europe exemplify how traditions have travelled far away from their places of origin and found a new, fertile ground on which to operate in the modern world (Park 1994, 153-154).

Religious traditions, almost by necessity, need to adapt to the new surroundings, since, as a result of migration, many things in the environment have changed and there is a need to find new forms, interpretations and functions (Warner 1998, 20-23). The social environment in which immigrant religious organizations function is largely something beyond immigrants' control. It is a situation in which they need to find their own place and come to terms with the opportunities and constraints it provides. Immigrants' adaptation is a two-way process, affecting both the immigrants as well as the local society (Ebaugh and Chafetz 2000, 325). Attitudes towards, and opinions about, immigrants play a significant role in the migrants' lives. They affect immigrants' opportunities for obtaining work, their enjoyment of life and even their possibilities for living in some regions. Negative attitudes can strengthen the natural tendency that draws immigrants to live close to each other and thus promote the creation of immigrant districts. In Finland, the degree of suspicion and racism varies significantly between immigrant and religious groups. People who are from non-European societies experience these more than others (Jasinskaja-Lahti, Liebkind and Vesala 2002, 134-137). With regard to religious prejudice, most non-Christian groups experience more intolerance, but also some actively proselytizing Christian groups, such as Pentecostalists and Jehovah's Witnesses are considered with suspicion. Orthodox migrants, however, enjoy a favorable climate in comparison to many other religions (Niemelä 2003, 145).

The status of the immigrants' religion is also worth noting. Are they in a minority or majority position and how does this differ from the situation in their homeland? If they were a persecuted minority in their homeland, they are probably satisfied if the new environment supports religious freedom; if the opposite is the case, their 
feelings may also be quite different. Furthermore, coming from a religious majority to a minority position can also lead to a closer interest in one's religion, because it is the first time that is has been questioned. The majority's religious identity is often more unconscious and less established than the minority's identity, because it has not been contested (Baumann 2002). Ebaugh and Chafetz (2000, 325-336) found this aspect to be among the most central features with regard to immigrants' religious organizations and how they develop. Most immigrants that come to Finland end in a religious minority position, because the Lutheran Church is culturally and numerically so dominant and only a small portion of immigrants have a Lutheran background. This is also true for the Orthodox immigrants, but they have the additional benefit of being members of a globally spread religion that already exists in the country, as well as enjoying a good reputation. Orthodox immigrants also become members of a church considered to be a basic part of the national heritage, with well-established institutions around the country as well as a functioning system of religious education in the Finnish school system.

\section{Structural adaptations}

Structural adaptation refers to the processes and strategies by which immigrants and their communities adapt to the new legal, social, cultural and organizational structures that differ in varying degrees from those of their societies of origin. In practice, from the host society's perspective it is a matter of to what extent the immigrants start to follow its rules, norms and values, and from the immigrants' point of view it is a question of how they can function well and acceptably in a new environment (Warner 1998, 20-23). Religious organizations are a common form of organization for migrants in a new environment and civil society, even though by no means the only one (Baumann 2002). Examples of other forms include cultural associations and political parties (e.g., Wahlbeck 1999). For some reason, religious organizations have been somewhat neglected in mainstream, post-war immigration research and largely in social scientific research in general, even though this is now rapidly changing in the post 9/11 world. Churches, mosques and other sanctuaries have become central meeting-points for many local migrant communities, which in cases of larger religious minorities have then tended to become divided along cultural, ethnic, national or sectarian lines (Baumann 2002; Ebaugh and Chafetz 2000, 13-20, 401-407). This means that the common basic unit is often, for example, a local Russian Orthodox or an Iraqi Shiite Muslim congregation, rather than a general Orthodox or Muslim assembly. However, there are also increasing numbers of multicultural or multiethnic congregations, as will be illustrated later in this article.

Organizational adaptation is also about the relationship between the religious organizations of the immigrants and the host society, which then indirectly affects the immigrants' views on religion. When the immigrants start to organize themselves officially, 
they also become subjects for local authorities and national legislation. Stephen Warner (1998) has argued that in the United States immigrant religious organizations adapt a congregational form that is predominant in American religious culture. While North American religious organization is somewhat different from its European counterpart, it is not so distinct with regard to lay-led religious organizations. Actually, there seem to be many more similarities than differences in the form of immigrant religious organizations when the European and American cases are compared, if we leave out certain organizational forms that are required by specific national legislation. In general, the organizations in both cases have a high-degree of lay-involvement and are usually voluntarily organized in a manner resembling the organizational structure of Christian congregations. In this respect, I think it is justifiable to take the American experience as one starting-point.

Migrants can also join already existing religious organizations and unite with other co-religionists or join an altogether new religion. In the first case, they often still try to keep their specific characteristics, even if the organization as such attempts to emphasize pan-religious and pan-cultural interpretations of the tradition (Ebaugh and Chafetz 2000, 330-331, 401-407; Hamberg 1999). In some cases a common religious background is not enough. For instance, the Tatar Muslims in Finland have not been willing to accept new members who do not have a Tatar background, even though they belong to the same Sunni tradition (Martikainen 2000, 207). Still, religion seems to be among the most prominent community-creating forces among migrants, even though it is not the only one.

The pervasive role of religion for immigrants does not lie solely in its nature as the provider of meaning, but comes rather from a combination of various aspects. As religion is usually closely tied to a particular local, regional or national culture, and often seen as its ultimate legitimization, the religious community provides, alongside family and home, a base for the practice of that particular tradition. In immigrant religious organizations - in addition to religious activities - a vast array of other, more or less, secular activities take place that are related to the culture of origin (Baumann 2002). Ebaugh and Chafetz (2000, 385-396) have identified three major ways in which traditional culture and ethnicity is reproduced in the organizations. First, by physically reproducing aspects of home-country religious institutions: these include church architecture, interior design and other visual representations, but also dress, sounds and smells are examples of this kind. Second, by incorporating ethnic practices and holidays into formal religious ceremonies, such as national independence and New Year's days. Third, congregationally related social activities are also important, including language-based fellowship groups and other activities, which often centre on the use of native vernaculars and the consumption of traditional food. In addition to these, there is the domestic practice of religion. The immigrant religious organization is 
often a more general cultural centre or base, a reminder of the homeland and an arena of sociability, rather than a purely faith-based community ${ }^{7}$. This also makes it less attractive for potential converts, although some converts are especially interested in the exoticism related to the tradition. If it is a question of a multi-ethnic organization, then the reproduction of ethnicity occurs in smaller groups within the community.

The organizations are also forums where social networks and capital are created which help both the old members and newcomers to find information, encouragement and advice on how to function meaningfully in the new environment (Ammerman 1997, 362-367). These, often informal, networks are highly efficient structures that are regularly based on ethnic solidarity. They may even function as a conscious missionary strategy by the organization in order to recruit new members, as newcomers usually seek places to enter the local society and its social networks to find friends, employment and the like (Ebaugh and Chafetz 2000, 371-382).

The use of the native vernacular in the community is a unifying as well as a possible source of conflict. Ebaugh and Chafetz $(2000,409)$ summarize as follows:

Immigrant congregations self-consciously select languages for formal services and religious education classes in pursuit of institutional goals, while their members unconsciously employ languages in informal contexts that can both enhance solidarity and promote disunity (...) Nonetheless, the use of an oldcountry language also provides a comfort zone for immigrants that enhances their sense of well-being and congregational commitment.

Thus, matters related to language are highly central for the immigrant members. They form a central part of the identity of, at least, the first generation. While the organizations need to be functional and choose one or two languages as the main channel of communication, they might be neglecting others in the process.

The socialization of the second generation to the religious tradition is one of the main tasks that immigrant religious organizations face and, almost universally, it plays an important role in their activities. The education usually consists of religious, cultural and linguistic elements regarded as necessary skills for the youth. The young people are, however, in-between cultures and striving to come to terms with the demands of the host society with regard to education, hobbies and the like. They might even find

\footnotetext{
${ }^{7}$ I will leave it open for further inquiry to what extent generational differences are meaningful in the reproduction of ethnicity. On that matter, see for instance Kivisto (2002) and ÖsterlundPötzsch (2003). For Finnish experiences among the second generation, see Alitolppa-Niitamo (2004) and Hautaniemi (2004).
} 
it embarrassing that their parents have such a keen interest in their tradition (Ebaugh and Chafetz 2000, 431-445). However, there are many signs that the second generation does not leave the religious tradition in question (Baumann 2002).

\section{Orthodox immigrants in Helsinki and Turku parishes}

The following section will discuss to what extent the developments described above can be found in two parishes of the Finnish Orthodox Church. The parishes function in the cities of Helsinki and Turku, which number among the largest immigrant centres of the country. The Orthodox Parish of Helsinki is the country's largest Orthodox parish and it has ca. 18,000 members. During the 1990s, the parish's membership grew by ca. $20 \%$, in large part because of international migration. In 2000, there were over 1,000 official members of immigrant origin. The parish employs several priests and provides a wide array of activities, including an international fellowship (Purmonen 2002, 20). In Turku, the local Finnish Orthodox parish works over a large area in south-western Finland, although almost $60 \%$ of its members live in or near the city of Turku. The church's membership has risen by ca. 25\% during the last 15 years. The growth in membership has been largely due to immigration from Eastern Europe. Current membership is ca. 2,500 and the members represent several national groups (Ratilainen 2002). Additionally, in both cities there are also separate Russian Orthodox communities (Nikita 2003).

The next section will attempt to answer the following questions. First, in which organizational ways have the parishes responded to the needs of the immigrants? Second, to what extent are issues related to religious services important for the immigrants? Third, do the parishes provide support for the immigrants' ethnic aspirations? Fourth, how has the religious education of children been taken into account? Fifth, what is the role of transnational contacts? A further discussion based on these questions and answers takes place in the next chapter "Global questions-Local answers". The discussion will question some common presuppositions about the role of ethnicity in forging religious solidarity in a multi-ethnic milieu.

\section{Organizational support}

Both the Turku and the Helsinki parishes have responded to the challenges of the new Orthodox immigration. St. Isaac of Niniveh - the International Orthodox Community of Helsinki Parish was founded in 1994 to serve the increasingly international membership of the parish. It supports the organization of the divine liturgy in different languages (Arabic, Amharic, Greek, English and Romanian), arranges discussion groups, takes part in inter-Orthodox dialogue, organizes exhibitions, food bazaars and family camps as well as publishing St. Isaac's News, an English language newsletter. The community consists of people from over 15 countries. Its monthly meetings have ca. 20 participants and in case of larger events, there can be more than 100 attendees. The members of 
this community can freely choose whether they will join the parish as formal members. It is this semi-official status that makes this community an organizational novelty (St. Isaac of Niniveh, 2001). The Orthodox Parish of Turku is smaller than the one in Helsinki, and no similar structures have been formed. However, the congregation provides space for different national groups if they want to organize activities on their own. So far, at least the Greeks and Romanians have used this possibility. They arrange meetings on a regular basis and classes for youth and children in the parish's premises (Ratilainen 2002). In this respect the Turku parish is more traditional with regard to religious organization than the one in Helsinki.

In both places the parish leaders support linguistic, ethnic and national diversity and try to provide possibilities for the group's own initiatives (Ratilainen 2002; Tenaw 2004). This support is essential for the international activity, as it could otherwise be difficult to find suitable and affordable meeting places. In a different setting it could well be that the parish's denial to provide space would lead to further segmentation of Orthodox activity in the locality, as well as to a distancing of the new members from the parish. So, at least on such an elementary level, the support of the local parish is essential for Orthodox unity in a particular context. The specific ethnic aspirations of a particular group need, therefore, to be in line with official parish policy. The parish leaders can also in this way control to some extent what kinds of activities take place in specific national or ethnic groups. Both cases, however, show that in order to integrate new members into the community, additional measures are required, and a practical solution is to support the wishes to create a space for group-specific activity.

\section{Religious services and key-individuals}

Much of the contemporary sociological literature on immigrant religions points to ethnicity as a source of difference and tension in the local context, but that can be somewhat misleading. In the new local context it can also be far more often a question of to what extent it is possible to receive religious services in the language to which one is accustomed. Ethnicity may be often secondary and of more importance is access to different kinds of religious services. According to the dean of the Turku Parish, among the most common requests by people of immigrant origin are queries related to services in their own language and possibilities for arranging a place for group meetings, including language teaching for children (Ratilainen 2002). This observation is almost universal also in other religious settings in Finland, where ethnicity is only rarely raised to a central place. Quite on the contrary, we can see that the failure of many religious organizations' to provide religious services in different languages does not necessarily lead to diminishing membership, but rather to a growing distance between different segments of the members. However, in this respect there is something else that becomes important. Namely the presence of co-ethnics, who are able to conduct the required religious practices in people's native languages. Parish and 
congregation leaders often stress how difficult it is to find a balance between the different aspirations and wishes, and equally often they state the need for multi-lingual religious activity. In this context they often use, if such are available, native clergy or lay-people, who are able to provide the required teaching in different languages. So, at least on a practical level, it appears that language is far more important than ethnicity (Martikainen 2004). Based on these limited observations, I would be ready to suggest that multiethnic membership in any organization places high demands on leadership. If the parish leaders are able and willing to use the 'ethnic resources' available in the community, they are able to both reduce the risk of splinter groups as well as make their organization more attractive for new, potential members.

\section{Ethnicity vs. multiculturalism}

Many of the Orthodox churches in diaspora have to live with the dilemma that Orthodoxy is often very closely related to a particular nationality or ethnicity. The historically close ties that many Orthodox churches have had with particular states become evident in the varied religious practices at the local level. This was not a problem for migrants in their countries of origin, where the status quo was for most not challenged, but in the contemporary multicultural climate the issue becomes central. How to cope with religious diversity within a single faith community? What is religious and what is cultural? The common discussions about culture and religion often aim at de-emphasizing ethnicity on behalf of other factors. The multicultural context also heightens immigrants' self-reflexivity and gives tools for reconstructing one's religious views. Veikko Purmonen, dean of the Helsinki Parish, makes the following comment on his multicultural parish in an interview in the St. Isaac's News (2/2001):

Despite of the different languages and the national traditions, we have been able to create one and united Orthodox community in our parish. In my view, this is very remarkable. In other Orthodox countries, in the so-called Diaspora Churches Orthodox faith followers representing different nationalities usually form their own communities. On the contrary, in our parish we endeavor to come closer with each other which has enabled us to maintain fraternal co-operation.

Multiculturalism is, thus, a different solution to the growing ethnic and national pluralism in a particular parish. Within certain limits, it accepts the divergent aspirations of its subgroups, but simultaneously it encourages respect for common interests. It could well be that when the number of people representing a particularistic tradition remains fairly small, the possibilities for multiculturalism are higher. However, as Dean Purmonen notes, this approach requires dedicated effort to keep different segments of the membership satisfied, or they might start searching for other possibilities. For instance, many Russian Orthodox have found it more convenient to join communities of the Russian Church in Finland (Nikita 2003) and among some of the Ethiopians, there 
are similar aspirations (Tenaw 2004). This leads us to wonder whether a multicultural community is an unstable social formation and what makes it attractive for the people involved.

\section{Religious education for the children}

Religious education is one of the most important reasons why migrants become active in a local religious organization. The socialization of the next generation is also a question of how to support one's identity in a situation where the surrounding society does not do it. Whereas particular ethnic and national groups often provide religious education, the parish also commonly provides it as well. The number and diversity of children receiving Orthodox religious education has risen significantly during the last decade. In the Finnish school system, religious education is an obligatory subject in which almost all children participate. Religious education teachers have often found it problematic to deal with such diverse groups (Ratilainen 2002). In the case of Islamic instruction this has also led to the invention of the so-called 'general Islam' that is taught instead of 'particular Islams' (Rosenqvist 2003). Whereas most Orthodox children are taught by native Finnish Orthodox, also in their case adaptations have been made in the school curriculum. In this way the children become part of the definitional battle of what are correct forms and practices. The children are in a difficult situation, if the difference between officially approved forms and domestic practices becomes too large.

Some solutions to this dilemma have already emerged. First, particular national groups have started their own religious education classes, where they are able to define matters on their own terms. The classes combine teaching of language, culture and religion so that the children will also have better knowledge their own background and its specific features (Ratilainen 2002). Second, one function that specific children's events, for instance summer camps, have is that they are good places to socialize with other children and members of the parish. Such events can reduce tensions between different segments of the community. If the parish leaders do not demand too much conformity from their members, it is quite likely that different segments of the membership can stay satisfied within the organization, even though they might have different views on some issues.

\section{Transnationalism}

Transnational connections are often mentioned as something of utmost importance in the current world (Levitt 2001). However, I would like to point out with the following examples that the role of such contacts can be quite different in various particular settings. The starting point is a relatively homogenous Finnish Orthodox context, which has only recently become multiethnic and especially so in only a few local parishes. The argument is that in the Finnish case, transnationalism can heighten the potential 
for religious conflicts. A common type of transnational contact is that between laity and religious specialists of a particular tradition. Also in Finland, many immigrant groups have established links with priests in other countries, often with the help of a local Finnish Orthodox parish (Ratilainen 2002; Tenaw 2004). Many of these contacts have happened in an 'ecumenical' fashion, so that the visitors have had the approval of the local church. However, the visitors are also simultaneously a resource for those immigrant members who are not satisfied with the current situation. In this context it often happens that the visitors also conduct religious services for particular national groups.

If the leadership of a particular parish accepts the presence of different religious views and practices, it must also carry the burden of its implications for local religious life. To bring in foreign clergy may cause unrest among the parish membership, but it can also stabilize some segments of it. The point is that it is not possible to predict what the outcomes of transnational interconnectivity are in a local context. In this way it can be argued that the inherent unpredictability of transnationalism is the price for the possible positive outcomes it may have. This reasoning is along the lines of how the anthropologist Arjun Appadurai (1996) views the global condition and its disjuctures. However, it is important for us to note that despite destabilizing effects of transnationalism, it can and may also have a stabilizing function.

\section{Global questions - local answers}

The underlying assumption in many studies of immigrant religions is that ethnicity remains central for the new immigrants. The examples cited above do not necessarily support that view. They rather underline the importance of the new religious context and the agency of particular immigrants who may want to challenge the ethnic nature of their religious tradition. Also questions related to religious leadership and authority are central. The Orthodox immigrants provide a good case study on this matter, because the Orthodox churches are often very closely tied to a particular national tradition. That is also the situation in Finland, where the Finnish Orthodox Church has often been legitimated from national history at the expense of international ties. Links to the Russian Church, even though recognized, have been treated somewhat ambivalently, which is in strong contrast to the solely positive image of connections with Constantinople, as a more distant point of reference (Loima 2004, 169-170).

However, it became obvious that there are many critical issues related to particular Orthodox practices and traditions that need to be resolved in the new setting. If the host church is willing to diminish its emphasis on certain issues, it can also benefit definitively from growing membership and enriched local practices. The Finnish church uses the Gregorian calendar, which was also a source of conflict in its early days, as the Russian Church as well as most of the other local Orthodox churches still follow the old, Julian calendar. However, not all of the new immigrants find this problematic, 
and many of them have adapted the Finnish custom. However, issues such as this still cause problems, when individual immigrants for various reasons are not willing to change their practices. Nevertheless, the issues can be resolved so that certain practices remain home-bound, and others are celebrated alongside the rest of the congregation in the church. This has been the policy of the Helsinki international fellowship.

Multiculturalism - the ideology of accepting a certain amount of difference that is related to national-cultural background - has emerged as a challenge to the ethnically and nationally defined churches. It remains to be seen how large its power is in creating religious solidarity over ethnic, cultural and linguistic boundaries, but at least in some cases it definitively does so. Multiculturalism could well become a solution for religious differences within certain religious traditions, as it accepts the inherent reflexivity of the global condition with its eroding effects on particularistic traditions. Multiculturalism is one solution to the dilemma that all particularistic traditions face, namely that of how to retain legitimacy, authority and authenticity in the face of cultural and religious pluralism.

\section{Discussion}

The arrival and establishment of immigrant religions as a result of growing international migration triggers many processes of structural adaptation both among the local as well as the immigrant populations. The main triggers for adaptation are practical reasons and objectives of immigrants' religious communities, so that they could function effectively in the new local context. However, structural adaptation is not a straightforward process of assimilation, but rather a creative and innovative one, which can lead to the formation of cultural innovations, based on established forms. This strengthens the view that the immigrant religions are not direct copies of the respective activities in their homelands, but rather new social formations. Moreover, it is difficult to predict the exact outcome of this process, even if some general developments are visible. The recognition of this dynamic allows us to appreciate the immigrant religious organizations better as potential forces of even wider cultural significance. Migration is a transformative force which, besides altering local religious landscapes, leads to the birth of hybrid cultural forms that transform aspects of particular religious traditions.

The contemporary multicultural climate in which immigrant religions function also enhances the possibilities for cultural creativity. Multicultural policies are not neutral politics without consequences, but rather affirmative ones promoting cultural, ethnic and religious difference. Multiculturalism is also part of the late modern reflexive project, in which culture, ethnicity and religion are expected to become aspects of one's lives, not self-defining centres. Multiculturalism expects recognition of difference, but also actively creates it. In the immigrant context different local traditions of a particular religion come into dialogue with each other, as well with other religions. 
In this context religious leaders are forced to rethink their orientation towards their tradition. For some, religion remains effectively bound to ethnicity, while others try to find the core of these different traditions and find other solutions.

The examples used in this article emphasize that the local context is still highly influential. As many migrant communities have active and lively relations with similar organizations in other countries, it could be asked to what extent these connections function as bridges of religious innovations and models. Further areas of interest with regard to the structural adaptation of immigrant religions could benefit from including more developments in the Christian churches to the, hitherto, slightly one-sided interest towards more alien religious traditions, such as Islam, Buddhism and Hinduism.

\section{Acknowledgements}

I would like to thank Dr. Jan Svanberg and Dr. Teuvo Laitila for their valuable comments on the manuscript.

\section{References}

Alitolppa-Niitamo, Anne. 2004. The Icebreakers: Somali-speaking Youth in Metropilitan Helsinki with a Focus on the Context of Formal Education. Publications of the Population Research Institute, Series D 42/2004. Helsinki: The Family Federation of Finland.

Ambrosius, Isä and Markku Haapio (editors). 1982. Ortodoksinen kirkko Suomessa. Heinävesi: Valamon luostari.

Ammerman, Nancy. 1997. Congregation and Community. New Brunswick, NJ: Rutgers University Press.

Appadurai, Arjun. 1996. Modernity at Large: Cultural Dimensions of Globalization. Minneapolis: University of Minnesota Press.

Baschmakoff, Natalia and Marja Leinonen. 2001. Russian Life in Finland 1917-1939: A Local and Oral History. Helsinki: Institute for Russian and East European Studies.

Baumann, Martin. 2000. Migration, Religion, Integration: Buddhistische Vietnamesen und hinduistischen Tamilen in Deutschland. Marburg: Diagonal-Verlag.

Baumann, Martin. 2002. Migrant Settlement, Religion and Phases of Diaspora, Migration: A European Journal of International Migration and Ethnic Relations 33-35: 93-117.

Castles, Stephen and Mark Miller. 2003. The Age of Migration: International Population Movements in the Modern World. Third edition, revised and updated. New York: Palgrave.

Eade, John (editor). 1997. Living the Global City: Globalization as a local process. London: Routledge.

Ebaugh, Helen and Janet Saltzman Chafetz (editors). 2000. Religion and the New Immigrants: Continuities and Adaptations in Immigrant Congregations. Walnut Creek, CA: Altamira.

Ebaugh, Helen and Janet Saltzman Chafetz (editors). 2002. Religion across Borders: Transnational Immigrant Networks. Walnut Creek, CA: Altamira.

Forsander, Annika. 2002. Luottamuksen ehdot. Maahanmuuttajat 1990-luvun suomalaisilla työmarkkinoilla. Helsinki: Väestöliitto.

Gustafsson, Göran. 1997. Tro, samfund och samhälle. Örebro: Libris. 
Hamberg, Eva. 1999. Migration and Religious Change. In: Religion and Social Transitions, edited by Eila Helander, pp. 71-86. Helsinki: University of Helsinki, Department of Practical Theology.

Hannerz, Ulf. 1996. Transnational Connections. London: Routledge.

Hautaniemi, Petri. 2004. Pojat! Somalipoikien kiistanalainen nuoruus Suomessa. Helsinki: Nuorisotutkimusverkosto.

Heino, Harri. 1997. Mihin Suomi tänään uskoo. Helsinki: WSOY.

Held, David; Anthony McGrew, David Goldblatt and Jonathan Perraton. 1999. Global Transformations: Politics, Economy and Culture. Cambridge: Polity.

Hinnels, John. 1997. The Study of Diaspora Religion. In: The New Penguin Handbook of Living Religions, edited by John Hinnels, pp. 682-689. London: Penguin Books.

Jasinskaja-Lahti, Inga, Karmela Liebkind and Tiina Vesala. 2002. Rasismi ja syrjintä Suomessa: Maahanmuuttajien kokemuksia. Helsinki: Gaudeamus.

Ketola, Kimmo. 2003. Uusi kansanomainen uskonnollisuus. In: Moderni kirkkokansa: Suomalaisten uskonnollisuus uudella vuosituhannella, edited by Kimmo Kääriäinen, Kati Niemelä and Kimmo Ketola, pp. 53-86. Tampere: Kirkon tutkimuskeskus.

Kilpeläinen, Hannu. 2000. Valamo - karjalaisten luostari? Luostarin ja yhteiskunnan interaktio maailmansotien välisenä aikana. Helsinki: SKS.

Kivisto, Peter. 2002. Multiculturalism in a Global Society. Oxford: Blackwell.

Laitila, Teuvo and Jyrki Loima. 2004. Nationalism and Orthodoxy: Two Thematic Studies on national Ideologies and their Interaction with the Church. Renvall Institute Publications 15. Helsinki: Helsinki University.

Levitt, Peggy. 2001. The Transnational Villagers. Berkeley: University of California Press.

Loima, Jyrki. 2004. Nationalism and the Orthodox Church in Finland 1895-1958. In: Nationalism and Orthodoxy: Two Thematic Studies on National Ideologies and their Interaction with the Church, edited by Teuvo Laitila and Jyrki Loima, pp. 93-203. Helsinki: Helsinki University, Renvall Institute.

Martikainen, Tuomas. 2000. Muslims in Finland: Facts and Reflections. In: Islam and Christianity in School Religious Education: Issues, approaches, and contexts, edited by Nils G. Holm, pp. 203-247. Åbo: Åbo Akademi University.

Martikainen, Tuomas. 2004. Immigrant Religions in Local Society: Historical and Contemporary Perspectives in the City of Turku. Åbo: Åbo Akademi University Press.

Murtorinne, Eino. 1995. Suomen kirkon historia 4: Sortovuosista nykypäiviin 1900-1990. Helsinki: WSOY.

Nevalainen, Pekka. 1999. Viskoi kuin luoja kerjäläistä: Venäjän pakolaiset Suomessa 1917_ 1939. Helsinki: SKS.

Niemelä, Kati. 2003. Suomalaisten sitoutuminen uskonnollisiin yhdyskuntiin. In: Moderni kirkkokansa: Suomalaisten uskonnollisuus uudella vuosituhannella, edited by Kimmo Kääriäinen, Kati Niemelä and Kimmo Ketola, pp. 122-147. Tampere: Kirkon tutkimuskeskus.

Nikita, Father. 2003. The person in charge of the Russian Orthodox Uspenije chapel community in Turku. Personal interview, notes.

Park, Chris. 1994. Sacred Worlds: An Introduction to Geography and Religion. London: Routledge.

Piiroinen, Petri (editor). 2002. Ortodoksisuutta eilen ja tänään: Helsingin ortodoksinen seurakunta 1827-2002. Helsinki: Helsingin ortodoksinen seurakunta.

Pohjanpää, Kirsti, Seppo Paananen and Mauri Nieminen. 2003. Maahanmuuttajien elinolot: Venäläisten, virolaisten, somalialaisten ja vietnamilaisten elämää Suomessa 2002. Helsinki: Statistics Finland. 
Purmonen, Veikko. 1984. Orthodoxy in Finland: An Historical Introduction. In: Orthodoxy in Finland: Past and Present, edited by Veikko Purmonen, pp. 13-21. Kuopio: Orthodox Clergy Association.

Purmonen, Veikko (editor). 1984. Orthodoxy in Finland: Past and Present. Kuopio: Orthodox Clergy Association.

Purmonen, Veikko. 2002. Helsingin ortodoksinen seurakunta 1900-luvun viimeisinä vuosikymmeninä. In: Ortodoksisuutta eilen ja tänään: Helsingin ortodoksinen seurakunta 1827-2002, edited by Petri Piiroinen, pp. 20-37. Helsinki: Helsingin ortodoksinen seurakunta.

Raivo, Petri. 1996. Maiseman kulttuurinen transformaatio: Ortodoksinen kirkko suomalaisessa kulttuurimaisemassa [cultural transformation of landscapes: The orthodox church in the Finnish cultural landscape], Nordia 25:1.

Ratilainen, Petri. 2002. Dean of the Turku Orthodox Parish. Personal interview, transcript.

Repo, Mitro. 1999. Ortodoksinen Suomi. In: Suomi: Maa, kansa, kulttuurit, edited by Markku Löytönen and Laura Kolbe, pp. 290-302. Helsinki: SKS.

Robertson, Roland. 1995. Glocalisation: Time-Space and Homogeneity-Heterogeneity. In: Global Modernities, edited by Mike Featherstone, Scott Lash and Roland Robertson, pp. 25-44. London: Sage.

Rosenqvist, Satu. 2003. Person in charge of the multireligious education in the City of Turku. Personal interview, notes.

St. Isaac of Niniveh. 2001. A brochure of the St. Isaac of Niniveh - the International Orthodox Community of Helsinki Parish. Helsinki

St. Isaac's News. 2001. A newsletter published by the St. Isaac of Niniveh - the International Orthodox Community of Helsinki Parish.

Tenaw, Shimelles. 2004. Chairman of St. Isaac of Niniveh Orthodox community in Helsinki. Personal interview, notes.

Wahlbeck, Östen. 1999. Kurdish Diasporas: A Comparative Study of Kurdish Refugee Communities. London: Macmillan.

Warner, R. Stephen. 1998. Immigration and Religious Communities in the United States. In: Gatherings in Diaspora: Religious Communities and the New Immigration, edited by R. Stephen Warner and Judith G. Wittner, pp. 3-34. Philadelphia: Temple University Press.

Österlund-Pötzsch, Susanne. 2002. American Plus: Etnisk identitet hos finlandssvenska ättlingar i Nordamerika. Helsingfors: Svenska litteratursällskapet i Finland.

\section{Statistics:}

Statistics Finland (2003): Membership in religious communities in Finland by nationality, country of birth and language. Helsinki: Statistics Finland.

The transcripts and notes of the interviews are in the possession of the author. 


\section{Appendix I}

Membership in the Finnish Orthodox church, Dec. 31 ${ }^{\text {st }}, 2002$.

\begin{tabular}{lcr}
\hline & By & By \\
& nationality & country \\
\hline Total: & 56,689 & 56,689 \\
Finland & 53,553 & 52,304 \\
Foreign & 3,136 & 4,385
\end{tabular}

Former Soviet Union area:

$\begin{array}{lrr}\text { Russia } & 1,978 & 2,716 \\ \text { Estonia } & 192 & 244 \\ \text { Former Soviet Union } & 140 & 216 \\ \text { Ukraine } & 136 & 26 \\ \text { Kazakhstan } & 39 & . . \\ \text { Belarus } & 28 & . . \\ \text { Moldova } & 12 & . . \\ \text { Armenia } & 10 & . . \\ \text { Lithuania } & 10 & . . \\ \text { Uzbekistan } & 10 & . . \\ \text { Latvia } & . . & 22\end{array}$

European countries and the USA:

$\begin{array}{lrr}\text { Greece } & 92 & 171 \\ \text { Romania } & 79 & 131 \\ \text { Croatia } & 75 & 38 \\ \text { Sweden } & 32 & 137 \\ \text { Bulgaria } & 24 & 58 \\ \text { USA } & 15 & 14 \\ \text { Former Yugoslavia } & 13 & 75 \\ \text { Macedonia } & 11 & . . \\ \text { Germany } & 10 & 40 \\ \text { Cyprus } & . . & 22\end{array}$

\section{Other countries:}

\begin{tabular}{lrr} 
Ethiopia & 24 & 59 \\
Iraq & 13 & 21 \\
Egypt &.. & 25 \\
Unknown & 80 & 214 \\
\hline
\end{tabular}

.. Less than 10 people

Source: Statistics Finland (2003): Membership in religious communities in Finland by nationality, country of birth and language.

Helsinki: Statistics Finland. 


\section{Appendix II}

Membership in the Finnish Orthodox church, Dec. 31 ${ }^{\text {st }}, 2002$.

\begin{tabular}{lr}
\hline & By mother tongue \\
\hline Total: & 56,689 \\
Finnish & 51,584 \\
Swedish & 611 \\
Saami & 90 \\
Other languages & 4,404 \\
& \\
Former Soviet Union & \\
area: & \\
Russian & 3,467 \\
Estonian & 70 \\
Ukrainian & 50 \\
Armenian & 20 \\
Georgian & 13 \\
& \\
European languages: & \\
Greek & 176 \\
Romanian & 164 \\
Serbo-Croatian & 91 \\
Bulgarian & 56 \\
English & 33 \\
Macedonian & 15 \\
German & 15 \\
Other languages: & \\
Arabic & \\
Tigrinja & \\
Amharic & 41 \\
\hline & 40 \\
& 32 \\
\hline & \\
& \\
& \\
& \\
& \\
& \\
& \\
&
\end{tabular}

Source: Statistics Finland (2003): Membership in religious communities in Finland by nationality, country of birth and language.

Helsinki: Statistics Finland. 